\title{
An Assessment of Resource Recovery Potential and Management of Municipal Solid Waste in Jeetpur Simara Sub-Metropolitan City, Nepal
}

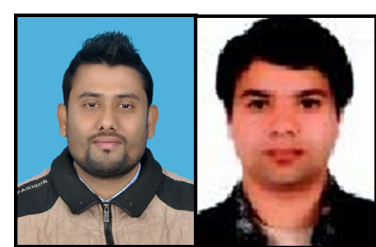

Yubraj Dahal

Abstract: Globally, rapid population growth, unmanaged urbanization, and increased income level have brought significant changes in quantity and composition of solid waste generation. In developing countries, solid waste disposal in open dump sites is widely practised as an easy and economical method of waste disposal. The increased quantity and composition of solid waste has posed a serious threat to public health and environment in developing countries. Hence, alternative waste disposal methods such as composting, recycling etc. can be potential options for sustainable solid waste management. Such methods will also reduce the waste volume prior to reaching the landfill and will increase the landfill's life. This paper aims to calculate the recovery value from Municipal Solid Waste (i.e. composting, biogas, paper, and plastic) in Jeetpur Simara Sub-Metropolitan City (JSSMC) in Nepal, and to calculate the area required for landfilling and dumping of biodegradable and residual solid waste respectively. Due to high biodegradable content $(8,400 \mathrm{~kg} /$ day), the recovery values from compost and biogas generation are studied. Optimum distribution of biodegradable solid waste among these two options is also evaluated. A combination of 6.4 tons/day for composting and 2 tons/day for landfilling with a net recovery of NRs. 29,064 per day is calculated. The recovery values from plastic and paper are calculated at NRs. 11,088 and NRs. 15,048 respectively. Hence, a total recovery value of NRs. 201.48 lakhs per year is suggested. This revenue is excluding the construction and operation cost required for the establishment of compost plant and landfill biogas collection system. The area required to landfill 2 tons/day of degradable waste is 0.876 hectares and 4.06 hectares to dump residual solid waste for a design period of 15 years. In case, biogas is not extracted, a total of 4.936 hectares' land is required for dumping the entire MSW generated from JSSMC. The revenue calculated reduces to NRs. 47,640 per day or NRs. 173.88 lakhs per year.

Keywords: Jeetpur Simara, resource recovery potential, organic waste composting, municipal solid waste management, landfill, Nepal

\section{Introduction}

M unicipal Solid Waste (MSW) management is an important issue worldwide (Chang et al., 1997). Globally, the amount of MSW, one of the most important by-products of any urban lifestyle, is growing even faster than the rate of urbanization (Hoornweg \& Bhada, 2012). Global MSW generated in 1997 was 0.49 billion tons with an estimated annual growth rate of $3.2-4.5 \%$ in developed nations and $2-3 \%$ in developing nations (Suocheng et al., 2001). Current global MSW generation level is approximately 1.3 billion tons per year and is expected to increase to approximately 2.2 billion tons per year by 2025 (Hoornweg \& Bhada, 2012). Solid waste management is a major challenge for the cities' authorities in developing countries. The challenge is due to the increasing generation of waste, the burden posed on the municipal budget due to the high costs associated with its management, the lack of understanding of a diversity of factors that affect the different stages of waste management and linkages necessary to enable the functioning of entire handling system functioning (Guerrero et al., 2013). Gomez (Gomez et al., 2011) observed that composition analysis of solid waste is essential to determine appropriate policy option for solid waste management in any city. Similarly, Dangi (Dangi et al., 2011) highlighted that solid waste management plans and policies should relate directly to waste composition. Thus, composition analysis guides the choice of appropriate policy

for sustainable SWM in developing countries. The composition analysis of MSW in developing countries has shown organic waste and paper waste as dominant fractions across the world. Developing countries have a high percentage of compostable organic matter in the urban waste stream, ranging from 40 to $85 \%$ of the total (Hoornweg \& Thomas, 1999). This implies high potentials for composting and recycling in developing countries. Composting is most appropriate for organic materials and paper while recycling is the most suitable for other wastes like plastic, metals, and glasses as found in the solid waste stream in developing countries (Harir et al., 2015). Composting is now considered as one of the best options for sustainable SWM (Khalib, 2014). Solid waste composting is a low cost, low technology, less pollution impact, and environmentally acceptable method compared to the current system of waste disposals in open dumps, being practised in the developing countries (Harir et al., 2015).

Only a few municipalities in Nepal are composting a small percentage of their waste, and a small percentage of wastes are burnt (Mishra \& Kayastha, 1998). As about two-thirds of the waste is organic, composting of organic waste and, recycling of paper and plastic through the application of other appropriate technologies can play an important role in sustainable solid waste management in Nepalese municipalities. Similarly, separation of organic waste also helps to keep 
the inorganic waste such as paper and plastics clean, which in turn increases their market value and potential for recycling. At present, only Bhaktapur municipality has a small plant with a capacity to process about 6 tons of waste per day. Several municipalities such as Kathmandu and Hetauda are promoting community and household composting. Currently, Hetauda is also in the process of setting up a compost plant of 3 tons per day capacity with the community and private sector participation (ENPHO \& Water Aid Nepal, 2008).

\section{Objectives}

The objectives of this study are outlined below:

1. To calculate the recovery value from MSW of JSSMC.

2. To present facts and encourage JSSMC to adopt integrated SWM practice and policies.

3. To encourage municipalities in Nepal for alternative solid waste disposal methods like composting, recycling etc.

4. To encourage private investors for SWM in the city.

\section{Study Area and Methodology}

The study area is JSSMC in Narayani zone of Central Nepal. It comprises 24 Wards within a total area of $909.6 \mathrm{~km}^{2}$. The present population of this city is 114,785 with a population growth rate of 2.25 per annum. The composition and quantity of MSW generation in JSSMC is given in Table 1.

\begin{tabular}{|c|c|c|}
\hline S. No. & Items Particulars & Values \\
\hline 1 & Per capita waste generation & $120 \mathrm{~g} /$ day \\
\hline 2 & MSW generation & 15 tons/day \\
\hline 3 & Composition of MSW & $\%$ by weight \\
& Organic & 56 \\
& Plastic & 19 \\
& Paper and paper products & 21 \\
& Inert & 4 \\
\hline
\end{tabular}

Table 1: Composition and quantity of MSW generation in JSSMC

Source: (Dahal \& Adhikari, 2018)

Based on the composition and quantity of MSW generation in JSSMC given by Dahal \& Adhikari, 2018, the necessary calculations for recovery values of the plastic, paper, compost and biogas are done as per the procedure outlined by Ramakrishna, 2016.

\section{Results and Discussion}

\section{Estimation of methane production}

The recovery product from landfills is methane. Methane production is estimated based on the average theoretical value of landfill gas production in landfill given by Carey \& Carty, 2000 and calculating 60\% of the total gas as methane. The estimated methane production per ton per day $=270 \mathrm{~m}^{3} /$ ton .

Recovery of total solid waste generated per day The necessary calculations are done as per the procedure outlined by Ramakrishna, 2016. The details are given below:

\section{Recovery value of biogas}

$1 \mathrm{~m}^{3}$ of biogas can generate $1.25 \mathrm{~kW} /$ hour of electricity $270 \mathrm{~m}^{3}$ of biogas can generate $1.25 \times 270=337.5 \mathrm{~kW} /$ hour electricity

Assuming $1 \mathrm{~kW} /$ hour costs NRs. 8 (residential uses), amount that can be recovered from 1 ton of solid waste $=$ NRs. 8 × $337.5=$ NRs. 2,700 per day

\section{Recovery value of compost and methane from landfill}

Total solid waste generated per day $=15,000 \mathrm{~kg} /$ day

Bio-degradable waste=8,400 kg/day (@ 56\%)

This can be used for composting as well as in a landfill.

Assuming 7 tons of solid waste is used for composting and remaining 1.4 tons for landfilling; calculations can be made as follows:

\section{Compost}

Recovery value of compost: 25-50\% (Richard, 2016)

Assuming 35\% recovery, compost recovered $=7 \times 0.35$ $=2.45$ tons per day

Recovery value @ NRs. 9,600 per ton (Agricultural Information, 2016) $=2.45 \times 9,600=$ NRs. 23,520

\section{Biogas from Landfill}

Biogas generation $=1.4 \times 270=378 \mathrm{~m}^{3}$ per day

Assuming cost of $1 \mathrm{~m}^{3}$ of biogas (IIT-Delhi, 2016) = NRs. 14 (Round figure) Recovery value $=378 \times 14$ $=$ NRs. 5,292 per day

The detailed breakdown of recovery values for different combinations of solid waste used for composting and landfilling are computed to study the best combination that can be used and is given in Table 2.

\begin{tabular}{|c|c|c|c|c|c|c|}
\hline & $\begin{array}{c}\text { S o I i d } \\
\text { w a s t e } \\
\text { o r r a I u e } \\
\text { compost } \\
\text { (tons) }\end{array}$ & $\begin{array}{c}\text { Recovery } \\
\text { f o m } \\
\text { compost } \\
\text { (NRs.) }\end{array}$ & $\begin{array}{c}\text { S o I i d } \\
\text { w a s t e } \\
\text { f o r r } \\
\text { la ndfill } \\
\text { (tons) }\end{array}$ & $\begin{array}{c}\text { B i o g a s } \\
\text { generated } \\
\text { (m3) }\end{array}$ & $\begin{array}{c}\text { Recovery } \\
\text { v a I u e } \\
\text { f r o m } \\
\text { b i o g a s } \\
\text { (NRs.) }\end{array}$ & $\begin{array}{c}\text { To t a I } \\
\text { va I u e } \\
=\text { a + b } \\
\text { (NRs.) }\end{array}$ \\
\hline 1 & 8.4 & 28224 & 0 & 0 & 0 & 28224 \\
\hline 2 & 7.4 & 24864 & 1 & 270 & 3780 & 28644 \\
\hline 3 & 6.4 & 21504 & 2 & 540 & 7560 & 29064 \\
\hline 4 & 5.4 & 18144 & 3 & 810 & 11340 & 29484 \\
\hline 5 & 4.4 & 14784 & 4 & 1080 & 15120 & 29904 \\
\hline 6 & 3.4 & 11424 & 5 & 1350 & 18900 & 30324 \\
\hline 7 & 2.4 & 8064 & 6 & 1620 & 22680 & 30744 \\
\hline 8 & 1.4 & 4704 & 7 & 1890 & 26460 & 31164 \\
\hline 9 & 0.4 & 1344 & 8 & 2160 & 30240 & 31584 \\
\hline
\end{tabular}

Table 2: Recovery value options for different combinations of biodegradable solid waste for composting and landfilling

From Table 2, it is noted that the best combination that generates maximum revenue is 9. Option-9 shows 8 tons of solid waste for landfilling and the remaining 0.4 tons for composting. This is not a best choice because this requires more land area for landfilling with minimum revenue from composting. The more is the quantity of solid waste for landfill disposal; the more 
is the area required, operation and maintenance cost and pollution. The integrated solid waste management is said to be best practised if the recovery value from the solid waste is high and the only small portion would be disposed of in a landfill. Recovery from the solid waste means an increase in revenue. Hence, an optimum combination for choosing the right combination of quantities for compost and biogas generation is attempted and is shown in Figure 1. From Figure 1, it is noted that the optimum quantities would result in revenue of NRs. 15,000 from compost and NRs. 15,000 from biogas recovery making a total recovery of NRs. 30,000 .

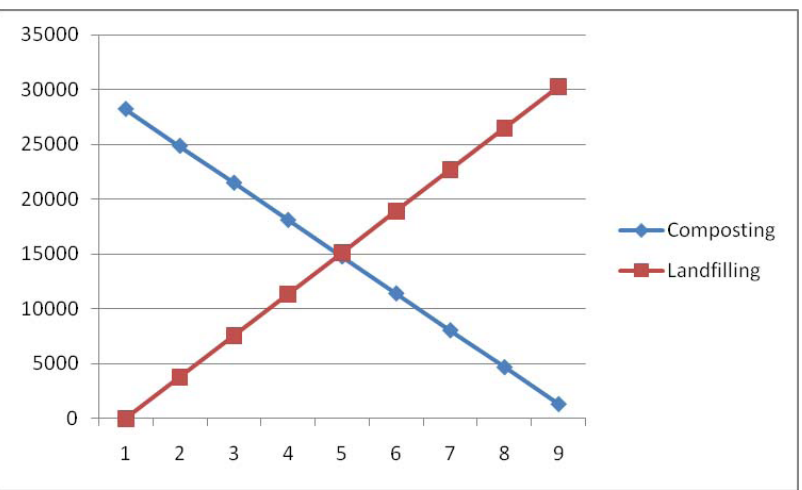

Figure 1: Recovery value (NRs.) comparison between composting and landfilling options

However, this is NRs. 1,584 less than the best combination (\#9). This is also not a right choice, since this requires more land area for landfilling with minimum revenue from composting. Hence, a combination of 6.4 tons for composting and 2 tons for landfilling with a net recovery of NRs. 29,064 per day is adopted as the optimum combination.

\section{Calculation of land required for landfilling of biodegradable waste}

Bio-degradable waste for land filling per day $=2$ tons $=$ $2,000 \mathrm{~kg}$ (as obtained above)

Bio-degradable waste for 15 years of filling $=2,000 \mathrm{x}$ $365 \times 15=10,950,000 \mathrm{~kg}$

Volume required for landfilling for 15 years $=$ total solid waste/density of solid waste

$=10,950,000 / 500$ (The density of MSW in JSSMC is $500 \mathrm{Kg} / \mathrm{m}^{3}$ (Average value obtained from baseline data collection. MSW is compacted to a $1 \mathrm{~m}^{3}$ container and weighted to calculate the density of MSW)) $=21,900 \mathrm{~m}^{3}$ Area required @ $5 \mathrm{~m}$ depth of filling=Volume $/$ depth = $21,900 / 5=4,380 \mathrm{~m}^{2}$

Assuming 100\% allowance for making roads, fencing, infrastructure and other facilities,

Area required $=2 \times 4,380=8,760 \mathrm{~m}^{2}=0.876$ hectares

\section{Recovery value for paper and plastic}

Non-biodegradable solid waste $=15,000 \times 0.44=6,600$ $\mathrm{kg} /$ day

\section{Recovery for paper}

Amount of paper: 21 x 6,600/100 =1,386 kg/day

Assuming $50 \%$ is not recoverable $=693 \mathrm{~kg} /$ day. Recovery value @ NRs. 16 per kg of paper=693 x $16=$
11,088 NRs. per day

\section{Recovery for Plastic}

Amount of plastic $=19 \times 6,600 / 100=1,254 \mathrm{~kg} /$ day

Assuming $50 \%$ is not recoverable $=627 \mathrm{~kg} /$ day

Recovery value @ NRS. 24 per kg of plastic $=627 \times 24=$ NRs. 15,048 per day

\section{Total recovery value from solid waste}

The total recovery value from solid waste $=$ Recovery value from biodegradable waste + Recovery value from non-biodegradable waste.

The total recovery value from MSW in JSSMC $=\mathbf{2 9 , 0 6 4}$ (Recovery value from adopted optimum combination) $+11,088+15,048=$ NRs. 55,200 per day or NRs. 201.48 lakhs per year

However, it should be noted that the recovery value is calculated without including the construction and operation costs for composting and landfilling. These investments can be recovered quickly in few years from the operation. The recovery value is maximum (52.64\%) from biodegradable waste. Moreover, recovery value of paper and plastics is $47.36 \%$. The recovery values from biodegradable waste and non-biodegradable waste are nearly equal. This suggests composting and landfilling of biodegradable waste while segregation of plastic and paper components should be done at the source of the generation with equal priority. Contamination of these components leads to the higher side of the non-recoverable portion and the recovery value will be reduced further.

\section{Disposal of residual solid waste in dumpsite}

The area of sanitary landfill obtained above for the disposal of biodegradable fraction of MSW is 0.876 hectare, where biogas recovery is possible. However, some portion of waste residues and fraction of nonrecoverable non-biodegradable solid waste should also be disposed off. This can be safely disposed in a dump site. The calculations made for this purpose are as follows:

1. Residue from compost making @ 35\% recovery rate

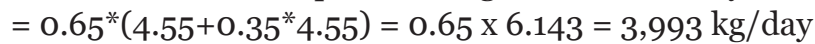
2. Non-recoverable fraction from non-biodegradable waste $=6,600-(693+627)=5,280 \mathrm{~kg} /$ day

3. Total residue from solid waste generated $=3,993+$ $5,280=9,273 \mathrm{~kg} /$ day

4. For 15 years of collection and disposal $=9,273 \times 365$ $\mathrm{x} 10=50,769,675 \mathrm{~kg}$

5 . Volume of this waste $=50,769,675 / 550=101539.35$ $\mathrm{m}^{3}$

6. Area required @ $5 \mathrm{~m}$ depth of filling =101539.35/5= $20307.87 \mathrm{~m}^{2}=2.03$ hectares

7. Add $100 \%$ allowance for creating internal roads, greenery, compound wall and other infrastructural facilities. Total area required $=2.03 \times 2=4.06$ hectares

Hence, the total area required for sanitary landfilling of biodegradable waste is 0.876 hectare and 4.06 hectares for dumping the residual solid waste. 
In case, the biogas is not recovered, a total of 4.936 $(0.876+4.06)$ hectares is required for dumping the entire MSW generated from JSSMC. The recovery value from the MSW will then be restricted to NRs. 47,640 per day or NRs. 173.88 lakhs per year.

Yubraj Dahal has recently completed Bachelor of Technology (B.tech) in Environmental Engineering at Department of Environmental Science and Engineering, Kathmandu University, Nepal. He has a keen interest in Environmental Impact Assessment, Air Pollution, Water and Wastewater Treatment, Solid Waste Management, Waste Management etc.

Corresponding E-mail: yubraj.dahal121@gmail.com

Bikash Adhikari, PhD, in Environmental Science (Waste Management)) is working as Assistant Professor at Department of Environmental Science and Engineering, Kathmandu University, Nepal. He is awarded with Nepal Bidhyabhusan 'Ka' from President of Nepal Rt. Honourable Bidhya Devi Bhandari. He is a member of University Grant Commission, Nepal and National Re-construction Authority, Nepal.

\section{E-mail: bikashadhikari@ku.edu.np}

\section{References}

Agriculture Information (2016). Newsletter Available on Internet at http://www.agricultureinformation. com/forums/sale/52727-vermicompost-sale.html.

Carey, P., \& Carty, G. (2000). Landfill Manuals: Landfill Site Design. EPA.

Chang, N. B., Lu, H. Y., \& Wei, Y. L. (1997). GIS Technology for Vehicle Routing and Scheduling in Solid Waste Collection Systems. Journal of Environmental Engineering, 123(9), 901-910.

Dahal, Y., \& Adhikari, B. (2018). Characterization and Quantification of Municipal Solid Waste in Jeetpur Simara Sub-Metropolitan City, Nepal. Hydro Nepal: Journal of Water, Energy, and Environment, 22, 4547.

Dangi, M. B., Pretz, C. R., Urynowicz, M. A., Gerow, K. G., \& Reddy, J. M. (2011). Municipal Solid Waste Generation in Kathmandu, Nepal. Journal of Environmental Management, 92 (1), 240-249.

Gomez, D. A., Wismer, S., \& Lopez, A. (2011). Evaluating the Mexican Federal District's Integrated Solid Waste Management Programme. Waste Management \& Research, doi: 10.1177/0734242X10380493.

Guerrero, L. A., Mass, G., \& Hogland, W. (2013). Solid Waste Management Challenges for Cities in Developing Countries. Waste Management, 33(1), 220-232.
Harir, A. L., Kasim, R., \& Ishiyaku, B. (2015). Exploring the Resource Recovery Potentials of Municipal Solid Waste: A Review of Solid Wastes Composting in Developing Countries. International Journal of Scientific and Research Publications, 5(4), 22503153 .

Hoornwerg, D., \& Bhada-Tata, P. (2012). What a Waste: a Global Review of Solid Waste Management. The World Bank.

Hoornweg, D., \& Thomas, L. (1999). What a Waste: Solid Waste Management in Asia. The World Bank.

IIT Delhi (2016). "Entrepreneurship Models on Biogas for Rural areas", Available on Internet at http:// web.iitd.ac.in/ vkvijay/Entrepreneurship\%20 Models\%20on\%20Biogas\%2ofor\%20Rural\%20 Areas.pdf

Khalib, S. N. B. B. (2014). Mini Review: Environmental Benefits of Composting Organic Solid Waste by Organic Additives. Bulletin of Environmental Science and Management, 2(1).

Mishra, S. B., \& Kayastha, R. P. (1998). Solid Waste Management. A Compendium on Environmental Statistics 1998, Nepal, 307-320.

Ramakrishna, V. (2016). Municipal Solid Waste Quantification, Characterization and Management in Rajam. IJES, 5, 40-47.Richard, T. L. (2016). "Municipal Solid Waste Composting: Physical Processing", Available on Internet at http:// compost.css.cornell.edu/MSWFactSheets/msw.fs1. html.

Richard, T.L. (2016). Municipal Solid Waste Composting: Physical Processing. Available on internet at http://compost.css .cornell.edu/ MSWFactSheets/msw.fs1.html, 2016.

Suocheng, D., Tong, K. W., \& Yuping, W. (2001). Municipal Solid Waste Management in China: Using Commercial Management to Solve a Growing Problem. Utilities Policy, 10(1), 7-11.

Water Aid Nepal (Editor) \& ENPHO (Editor) (2008). Solid Waste Management in Nepal. Water Aid Nepal \& Environment and Public Health Organization (ENPHO), Kathmandu. 